Рекомендована д. фрармац. наук, профр. І. О. Журавель

УДК 581.45.088.6:582.991

DOI 10.11603/2312-0967.2018.3.9343

\title{
МОРФОЛОГО-АНАТОМІЧНЕ ДОСЛІДЖЕННЯ ЛИСТКІВ СЕРПІЮ УВІНЧАНОГО (SERRATULA CORONATA L.)
}

\author{
(сС. М. Марчишин ${ }^{1}$, Т. О. Атаманчук ${ }^{1}$, Д. Б. Рахметов ${ }^{2}$, Л. М. Сіра ${ }^{3}$ \\ ДВНЗ «Тернопільський державний медичний університет імені І. Я. Горбачевського \\ МОЗ України» ${ }^{1}$ \\ Національний ботанічний сад імені. М. М. Гришка НАН України², Київ \\ Національний фрармацевтичний університет³ ${ }^{3}$ Харків \\ svitlanafarm@ukr.net
}

\begin{abstract}
Мета роботи. Встановлення морфолого-анатомічних діагностичних ознак листків серпію увінчаного.
Матеріали і методи. Мікропрепарати виготовляли з висушених листків, фріксованих у суміші спирт-гліцерин-вода (1:1:1) і досліджували загальноприйнятими методами з використанням мікроскопа Item: PB -2610, фоотофіксацію результатів здійснювали фротокамерою Samsung PL50.

Результати й обговорення. Листки. Розеткові і низові стеблові листки довгочерешкові, великі. В прикореневій розетці у середньому приблизно 6 непарноперистих листків 3 4-7 парами довгасто-ланцетних бічних сегментів. Стеблові листки серединної фрормації почергові, короткочерешкові або сидячі, перисто-роздільні або розсічені, зісподу сизуваті, зверху темно-зелені або з червонуватим відтінком. Край жорсткий, нерівномірно-великопилчастий, зубці на кінці з гострим білуватим хрящуватим шипиком. По жилках - рідке опушення.

Листковапластинка стеблових листків за будовою гіпостоматична, дорсовентральназ достатньо диореренційованим мезофрілом. Головна жилка стеблового перисторозсіченого листка, що на ділянках між сегментами, сідлоподібної форми. Колатеральних провідних пучків 9, крупніші чергуються 3 дрібнішими. У бічних відрогах проходить по 2 маленьких концентричних пучечки.

На мікропрепаратах з поверхні клітини верхньої епідерми листкової пластинки ізодіаметричні, слабохвилясті, продихи відсутні.

Клітини епідерми нижньої сторони пластинки дрібніші, із більш звивистими оболонками. Продихів багато, округлоовальні, аномоцитного типу, оточені 3-5 клітинами епідерми. Подекуди вздовж жилок, зрідка між ними епідерма 3 довгими 3-5-клітинними, тонкими гострими волосками.

Висновки. Вивчено морфолого-анатомічні ознаки серпію увінчаного та визначено основні макро- та мікроскопічні діагностичні ознаки листків, які будуть використані при стандартизації лікарської сировини - розробці методів контролю «Серпію листя».
\end{abstract}

Ключові слова: серпій увінчаний; листки; морфолого-анатомічна будова; діагностичні ознаки.

Вступ. Серпій увінчаний (Serratula coronata L.) мичкуватокоренева полікарпічна напіврозеткова багаторічна трав'яниста рослина-медонос родини Asteraceae (рис. 1). За життєвою фрормою - гемікриптофріт, оскільки бруньки відновлення закладаються близько до поверхні ґрунту й покриваються на зиму відмерлою надземною частиною. У дикому стані Serratula coronata зустрічається на сухих луках, по узліссях, в чагарниках північної частини Степу, у Лісостеповій зон та південній частини Полісся [1].

Серпій увінчаний використовують у народній медицині і $є$ перспективним для офріцинальної завдяки багатому хімічному складу і наявності полігідроксильованих стероїдів (екдистероїдів), джерелом яких ввжається офріційна лікарська рослина-Rhaponticum carthamoides (Willd. Iljin). Екдистероїди цінні тим, що виявляють антиоксидантну, адаптогенну анаболічну, мембраностабілізувальну, імуномодулюючу антигіпоксичну, стресопротекторну та інші види активності $[2,3,4]$.

У джерелах наукової літератури відомостей про дослідження серпію увінчаного недостатньо, тому метою наших досліджень було встановлення морфолого-анатомічних діагностичних ознак листків серпію увінчаного, заготовлених на дослідних ділянках відділу культурної фрлори Національного ботанічного саду імені М. М. Гришка НАН України в м. Києві під час масового цвітіння рослини у 2017 році.

Методи дослідження. Мікропрепарати виготовляли з висушених листків, фріксованих у суміші спиртгліцерин-вода (1:1:1) [5, 6] і досліджували загальноприйнятими методами з використанням мікроскопа

ISSN 2312-0967. Pharmaceutical review. 2018. № 3 
Item: РВ -2610, фротофріксацію результатів здійснювали фротокамерою Samsung PL50.

Результати й обговорення.

Макроскопічні ознаки листка серпію увінчаного

Розеткові і низові стеблові листки довгочерешкові, великі. В прикореневій розетці у середньому приблизно 6 непарноперистих листків із 4-7 парами довгасто-ланцетних бічних сегментів. Стеблові листки серединної формації почергові, короткочерешкові або сидячі, перисто-роздільні або розсічені, зісподу сизуваті, зверху темно-зелені або з червонуватим відтінком. Верхівковий сегмент великий, бічні сегменти у кількості 4-8 пар, довгасто-еліптичні або яйцеподібно-ланцетні. Край жорсткий, нерівномірно-великопилчастий, зубці на кінці з гострим білуватим хрящуватим шипиком. По жилках - рідке опушення.

Мікроскопічний аналіз листка серпію увінчаного

Листкова пластинка стеблових листків за будовою гіпостоматична, дорсовентральна з достатньо дисеренційованим мезофрілом. Головна жилки стеблового перисторозсіченого листка, що на ділянках між сегментами, сідлоподібної фрорми (рис. 2, А). Колатеральних провідних пучків 9, крупніші чергуються 3 дрібнішими. У бічних відрогах проходить по 2 маленьких концентричних пучечки.

Під епідермою, вкритою шаром кутикули, знаходиться коленхіма, що переходить від кутової до пухкої і надалі - у пухку паренхіму. Ближче до основи листкової пластинки спостерігається руйнація клітин паренхіми між пучками жилки і збільшення механічних елементів пучка.

Головна жилка сегментів листка (рис. 2, Б) має рельєснні виступи, виповнені кутовою і кутово-пухкою коленхімою: 3 верхньої сторони виступ клиноподібний, загострений, а з нижньої - крупніший, сфреричної фрорми. Провідну систему жилки складає великий центральний провідний пучок і два бічних меншого розміру. Пучки округло-овальні, колатеральні, 3 2-3-шаровою склеренхімною обкладкою і добре розвиненою променистою ксилемою. Бічні жилки першого і другого порядків також укріплені коленхімою. Серед обкладкової паренхіми ендодерми пучків листка трапляються клітини з темно-червоним, майже коричневим вмістом.

На мікропрепаратах 3 поверхні (рис. 3) клітини верхньої епідерми листкової пластинки ізодіаметричні, слабохвилясті, продихи відсутні. Клітини епідерми нижньої сторони пластинки дрібніші, із більш звивистими оболонками.

Продихів багато, округло-овальні, аномоцитного типу, оточені 3-5 клітинами епідерми. Подекуди вздовж жилок, зрідка між ними, епідерма з довгими 3-5-клітинними, тонкими гострими волосками (рис. 3,3). Біля їх основи добре помітна розетка із 7-8 великих прямостінних епідермальних клітин. По краю пластинки епідермальні волоски короткі, міцні, орієнтовані доверху (рис. 3,5). Складаються 3 підведеної
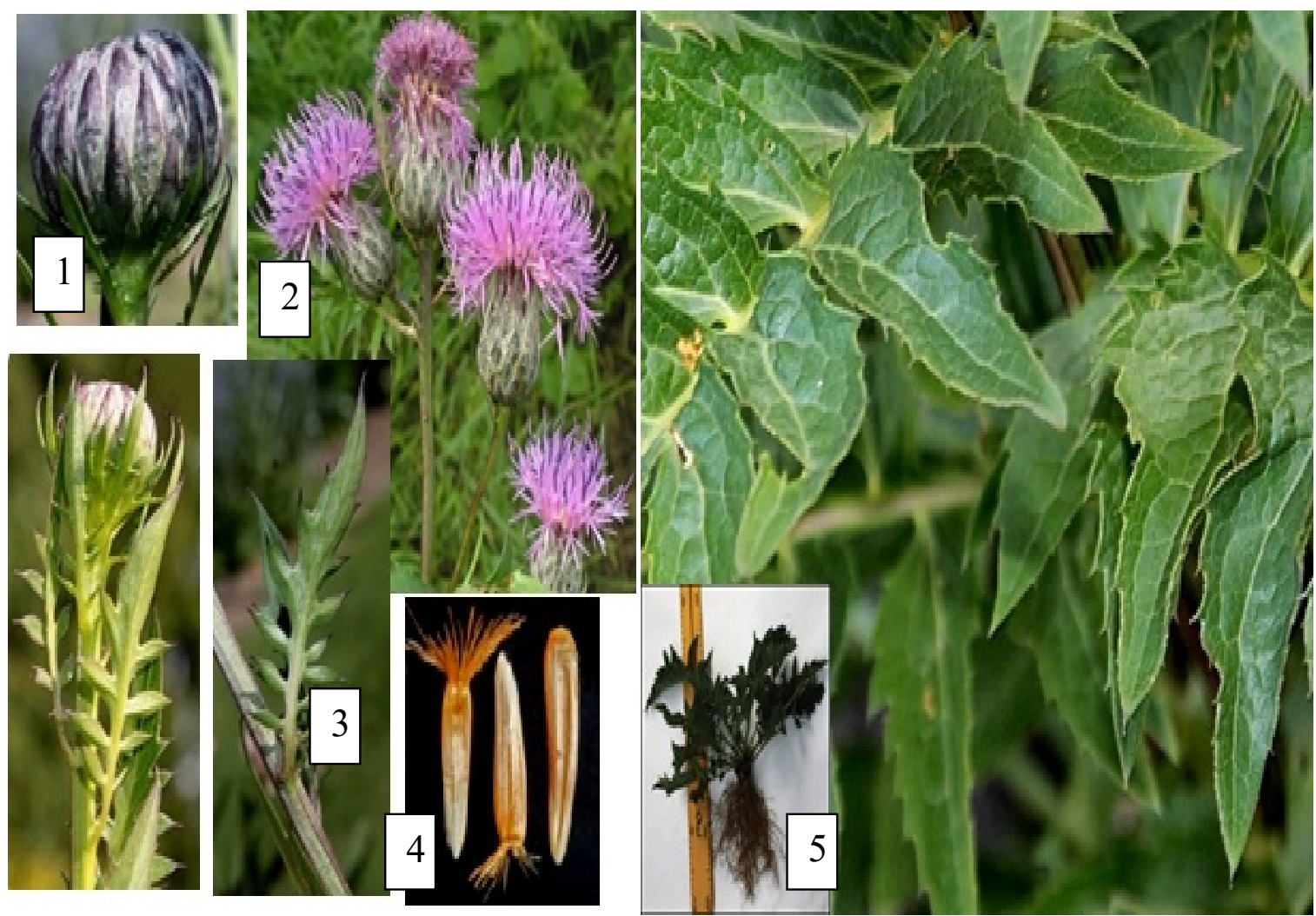

Рис. 1. Зовнішній вигляд надземних органів Serratula coronata: 1- пуп'янок, 2- суцвіття; 3- листок; 4- сім'янка; 5- іматурна рослина

ISSN 2312-0967. Фармацевтичний часопис. 2018. № 3 
Фітохімічні дослідження
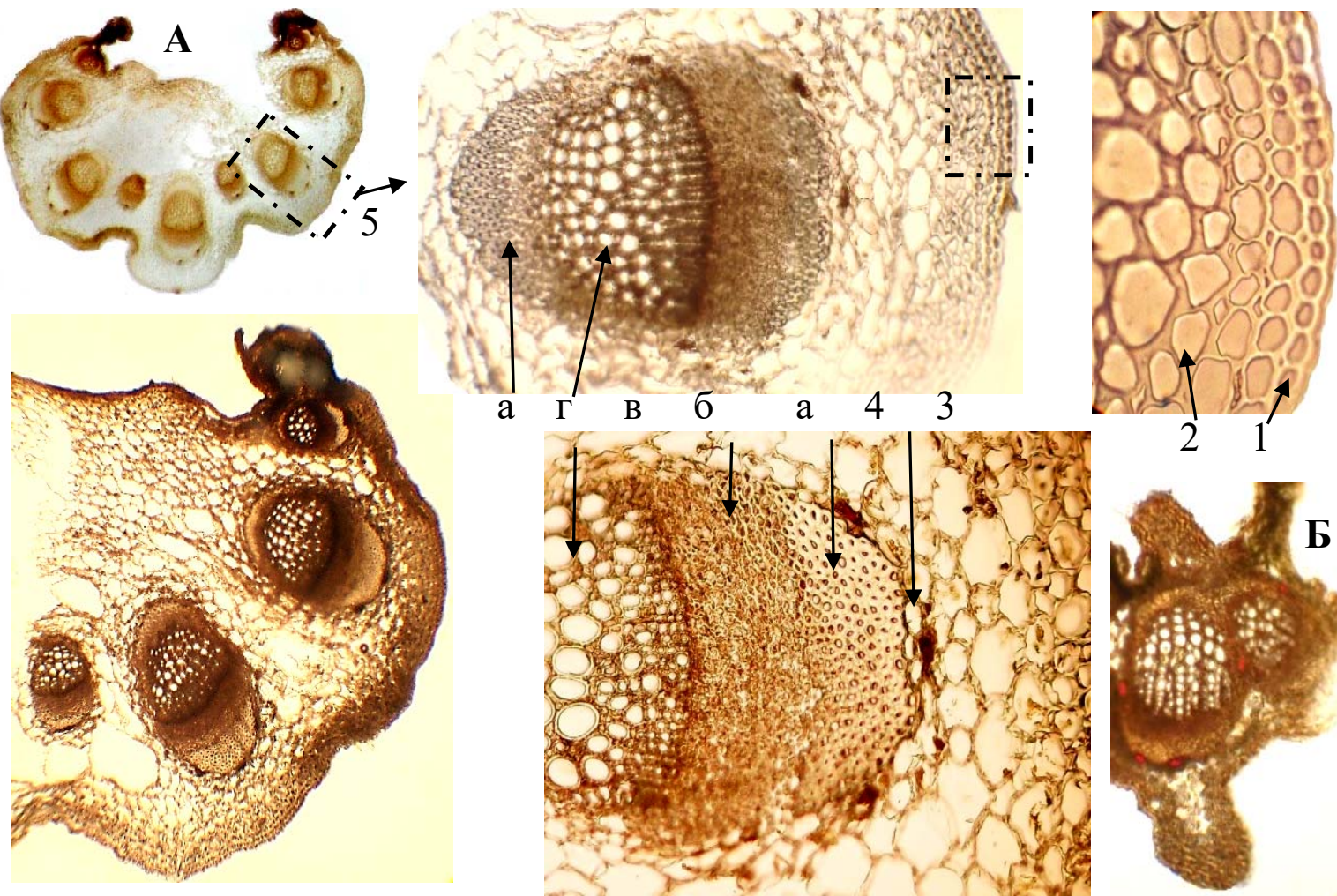

Рис. 2. Фрагменти поперечних зрізів стеблового листка Serratula coronata :

A - головної жилки між сегментами, Б - центральної жилки сегмента: 1 - епідерма, 2 - коленхіма, 3 - паренхіма, 4 - ендодерма, 5 - колатеральний провідний пучок: а - склеренхіма, б - провідна фрлоема, в - камбій, г - ксилема.

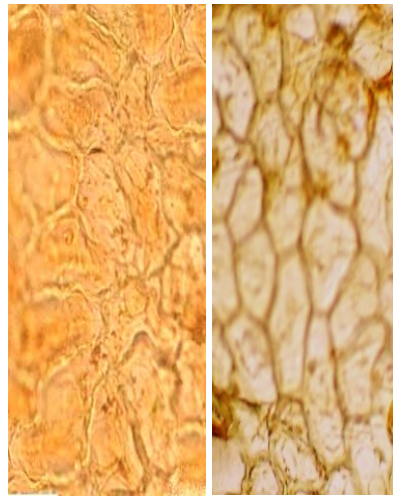

1

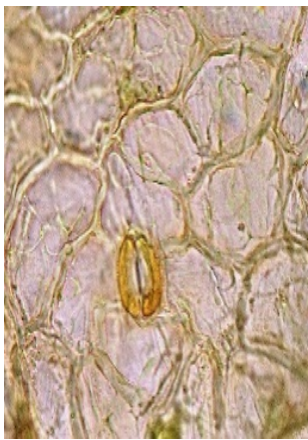

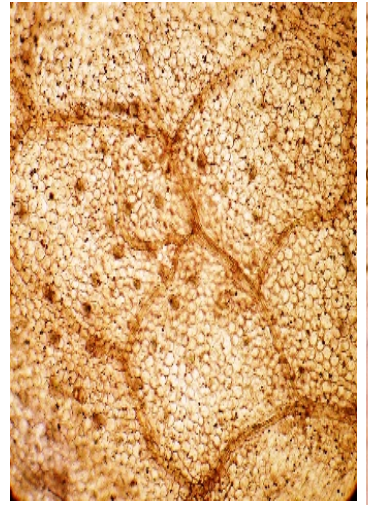
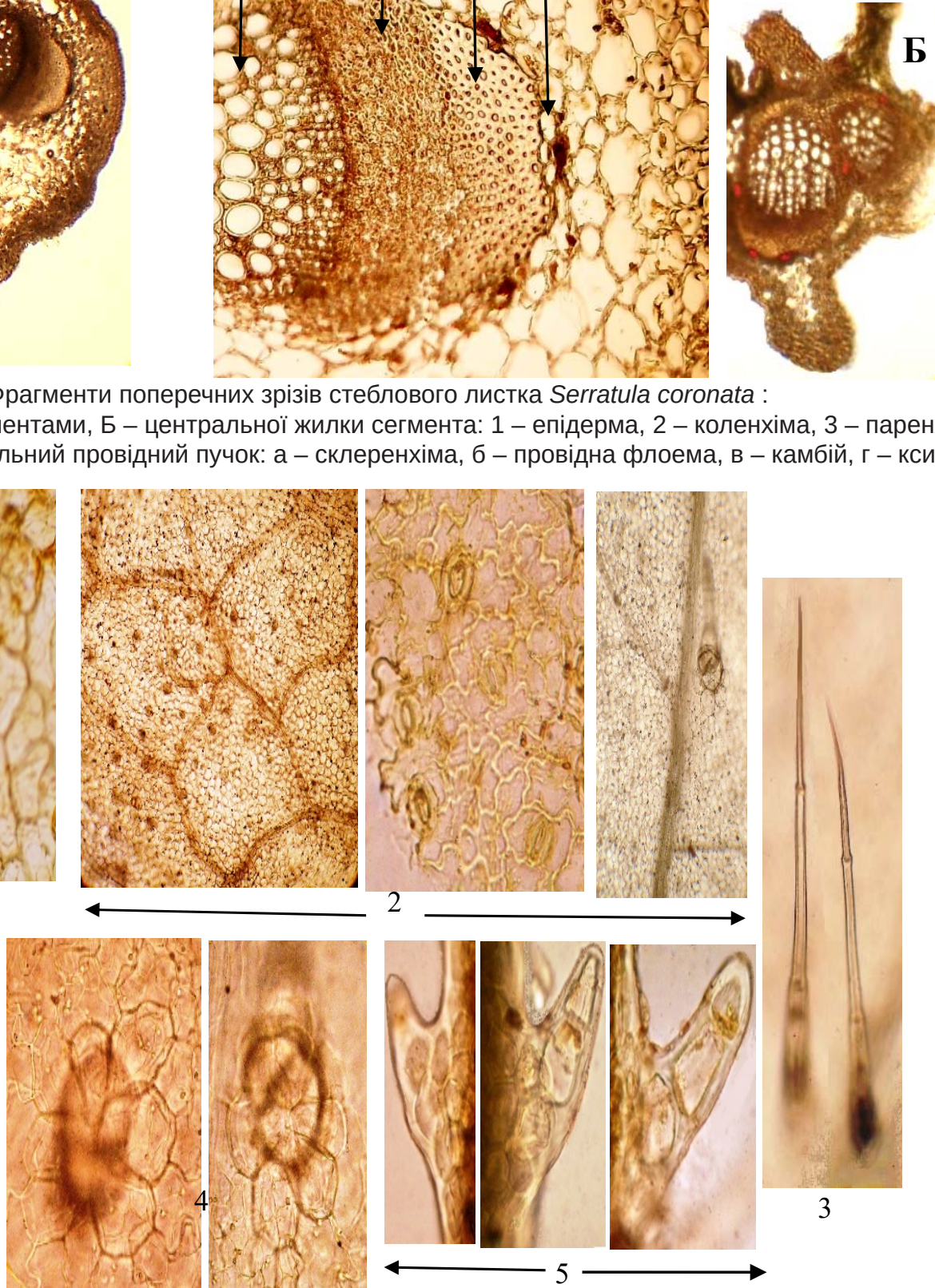

\section{(5)}

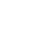


підставки і 2-3 клітин, що мають потовщену оболонку і поздовжні складочки кутикули.

Висновки. Вивчено морфолого-анатомічні ознаки серпію увінчаного та визначено основні макро- та мікроскопічні діагностичні ознаки листків, які будуть використані при стандартизації лікарської сировини - розробці методів контролю якості (МКЯ) «Серпію листя».

\title{
МОРФОЛОГО-АНАТОМИЧЕСКОЕ ИССЛЕДОВАНИЕ ЛИСТЬЕВ СЕРПУХИ ВЕНЦЕНОСНОЙ (SERRATULA CORONATA L.)
}

\author{
С. М. Марчишин ${ }^{1}$, Т. О. Атаманчук ${ }^{1}$, Д. Б. Рахметов ${ }^{2}$, Л. М. Серая ${ }^{3}$ \\ Украины» ${ }^{1}$ \\ Национальный ботанический сад имени Н. Н. Гришко НАН Украины ${ }^{2}$, Киев \\ Национальный фрармацевтический университет, Харьков \\ svitlanafarm@ukr.net
}

гвУз «Тернопольский государственный медицинский университет имени И. Я. Горбачевского Мз

Цель работы. Установление морфолого-анатомических диагностических признаков листьев серпухи венценосной. Материалы и методы. Микропрепараты изготавливали из высушенных листьев, фриксированных в смеси спиртглицерин-вода (1: 1: 1) и исследовали общепринятыми методами с использованием микроскопа Item: PB -2610, фотосриксацию результатов осуществляли фротокамерой Samsung PL50.

Результаты и обсуждение. Листья. Розеточные и низовые стеблевые листья длинночерешковые, крупные. В прикорневой розетке в среднем около 6 непарноперистыми листьев с 4-7 парами продолговато-ланцетных боковых сегментов.

Стеблевые листья срединной формации очередные, короткочерешковые или сидячие, перисто-раздельные или рассеченные, снизу сизоватые, сверху темно-зеленые или с красноватым оттенком. Край жесткий, неравномернокрупнопылчастые, зубцы на конце с острым беловатым хрящеватым транзакцией. По жилкам - редкое опушение. Листовая пластинка стеблевых листьев по строению гипостоматична, дорсовентральная с достаточно диффреренцированным мезофиллом. Главная жилки стеблевой перисторассеченных листа, что на участках между сегментами, седловидной фрормы. Коллатеральных проводящих пучков 9, крупные чередуются с мелкими. В боковых отрогах проходит по 2 маленьких концентрических пучочка.

На микропрепаратах с поверхности клетки верхней эпидермы пластинки изодиаметричны, слабо волнистые, устьица отсутствуют.

Клетки эпидермиса нижней стороны пластинки мелкие, с более извилистыми оболочками. Устьиц много, округлоовальные, аномоцитного типа, окруженные 3-5 клетками эпидермиса. Кое-где вдоль жилок, изредка между ними эпидерма с длинными 3-5-клеточными, тонкими острыми волосками.

Выводы. Изучены морфолого-анатомические признаки серпухи венценосной и определены основные макрои микроскопические диагностические признаки листьев, которые будут использованы при стандартизации лекарственного сырья - разработки МКЯ «Серпухи листья».

Ключевые слова: серпуха венценосная; листья; морфолого-анатомическое строение; диагностические признаки.

\section{MORPHOLOGICAL AND ANATOMIC INVESTIGATION OF SERRATULA CORONATA L. LEAVES}

\section{S. M. Marchyshyn ${ }^{1}$, T. O. Atamanchuk ${ }^{1}$, D. B. Rakhmetov' ${ }^{2}$, L. M. Sira ${ }^{3}$}

I. Horbachevsky Ternopil State Medical University ${ }^{1}$

M. Hryshko National Botanic Garden of the NAS of Ukraine ${ }^{2}$, Kyiv

National University of Pharmacy ${ }^{3}$, Kharkiv

svitlanafarm@ukr.net

The aim of the work. Determining of morphological and anatomical diagnostic signs of leaves of the investigated species. Materials and Methods. The micronutrients were made from dried leaves fixed in a mixture of alcohol-glycerine-water (1: 1: 1) and studied by conventional methods using the Microscope Item: PB-2610, and the results were photophixized by the Samsung PL50.

Resuls and Discussion. Leaves. Rosette and grass root leaves are macropodous, large. In the near root rosette, on average about 6 unpaired leaves with 4-7 pairs of oblong-lanceolate lateral segments. The cormophytic leaves of the

ISSN 2312-0967. Фармацевтичний часопис. 2018. № 3 
median formations are alternate, micropodous or sessile, pinnate-separated or cut, lobed with lace, dark green or reddish shade above. Edge is rigid, unevenly-large-pollen, the spikes on the end with a sharp whitish cartilaginous spine. A fluid skirt is on the veins.

The leaf plate of the stem leaves in the structure is gipostomatic, dorsoventral with a sufficiently differentiated mesophilus. The main veins of the stem pinnatifid leaf, that on the areas between the segments are saddle-shaped. The collateral conductive clusters 9, the larger alternate with smaller ones. There are two small concentric clusters in the lateral spurs.

On micronutrients, from the surface of the cell of the upper epidermis of the leaf plate isodimetric, weakly wavy, the stomata are absent.

The epidermis cells of the lower side of the plate are smaller, with more winding membranes. Stomata are many, round-oval, anomocytic type, surrounded by $3-5$ epidermis cells. Somewhere along veins, occasionally between them an epidermis with long 3-5-cell, thin sharp hairs.

Conclusions. The morphologic-anatomical features of the saw-wort were studied, and the main macroscopic and microscopic diagnostic features of the leaves were used, which would be used for standardization of medicinal raw materials - the development of control methods of saw-wort leaves.

Key words: saw-wort; leaves; morphologic and anatomic structure; diagnostic signs.

\section{Список літератури}

1. Атлас : учебное пособие : в 3-х томах / [И. А. Самылина, В. А. Ермакова, Н. В. Бобкова и др.]. - М. : ГЭОТАР-Медицина, 2010. - Т 3. - 488 с.

2. Интродукция - основа развития лекарственного растениеводства / [Г. И. Климахин, Н. В. Макарова, В. В. Семикин и др.]. - Библиогр., 2012. - № 1. - С. 23-28.

3. Фармакогностическое изучение плодов серпухи венце-

\section{References}

1. Samylina IA, Ermakova VA, Bobkova NV. Atlas: a tutorial: in 3 volumes. [Атлас: учебное пособие: в 3-х томах] Moscow: Geotar-Medicine; 2010. Russian.

2. Klimakhin GI. [Introduction - the basis for the development of medicinal plant growing]. 2012;1: 23-8. Russian.

3. Komissarova Eyu, Vandyshev VV, Miroshnikova EA [Pharmacognostic study of the fruits of the venetian

носной / Е. Ю. Комиссарова, В. В. Вандышев, Е.А.Мирошникова [и др.] // Вестник РУДН. - 2014. - № 3. - С. 20. 4. Новые фрлавоноиды растения Serratula coronata L. I [А. В. Мягчилов, л. И. Соколова, П. Г. Горовой и др.]. М., 2017. - Т. 51, № 2. - С. 23-27.

5. Справочник по ботанической микротехнике. Основы и методы / [Р. П. Барыкина, Т. Д. Веселова, А. Г. Девятови и др.]. - М. : Изд-во МГУ, 2004. - 312 с.

6. Фурст Г. П. Методы анатомо-гистохимического исследования растительных тканей / Г. П. Фурст. - М. : Наука, 1979. - 154 с.

venous]. Vestnik RUDN. 2014;3: 20. Russian.

4. Myagchilov AV. New flavonoids of the plant Serratula coronata L. [Новые фрлавоноиды растения Serratula coronata L.] Moscow. Russian.

5. Barykina RP, Veselova TD, Devyatovi AG. Handbook of botanical microtechnology. Basics and methods. [Справочник по ботанической микротехнике. Основы и методы] Moscow: MSU Publishing house; 2004. Russian.

6. Furst GP. Methods of anatomo-histochemical study of plant tissues [Методы анатомо-гистохимического исследования растительных тканей] Moscow: Science; 1979. Russian.

Отримано 27.06.2018

ISSN 2312-0967. Pharmaceutical review. 2018. № 3 